\title{
MENTAL-HEALTH POLICY IN ONTARIO COMPARED TO POLICY FOR PERSONS WITH DEVELOPMENTAL HANDICAPS
}

\author{
HARVEY G. SIMMONS \\ York University
}

\begin{abstract}
It is generally agreed that policy for developmentally handicapped people in Ontario has been more successful than mental-health policy. The reasons for this are explained in terms of nine key variables which have a major impact on policy: language, money, pressure groups, the press, opposition political parties, the bureaucracy, the minister of health, the professions, and the law. No ranking of these variables is attempted because, it is argued, it is impossible to capture the flow of politics by establishing a hierarchy of influences.
\end{abstract}

Why some policies succeed and others fail is a central question in politics. One way to approach the question is through comparative analysis (Przeworski \& Teune, 1970). An accepted means is to compare policies which, although similar on a number of dimensions, vary in areas chosen for comparison. In this case, mental-health policy in Ontario is compared with policy for developmentally handicapped people. Although both policies are aimed at disabled people, it is generally agreed in Ontario that policy for the developmentally handicapped has been more successful than mental-health policy.

The measure of judgement of relative success or failure is more difficult than may appear at first sight partly because different criteria may be used, and partly because hard data, statistical or otherwise, may be incommensurable. With this caveat in mind, one major criterion is the relative degree to which the government has provided community services for the two groups under consideration. Over the past few decades, policymakers and activists in both fields agreed that insufficient government funds were devoted to community services for developmentally handicapped and mentally ill people. The whole thrust of policy has been to reduce the resident populations in psychiatric hospitals and institutions for the developmentally handicapped and to integrate people into the community (Department of Health, 1974).' Because it is impossible to obtain hard data on the number and kind of community services provided, one indirect measure of the relative commitment to community services is the amount of money spent for such services by the two ministries involved.

The 1989-90 Program and Resources Summary for the Ministry of Community and Social Services (ComSoc), tells us the ministry expected to spend a total of $\$ 162,600,642$ on operating expenses for community resource centres and accommodation services in $1988-89$, both of which provide a wide variety of resi- 
dential and support services for developmentally handicapped people outside a large institutional setting (Ministry of Community and Social Services, 1989). In that year, the ministry helped subsidize 3,978 beds for adults and 836 beds for children in various forms of community accommodation.

By comparison, the 1990-91 Estimates Briefing Report from the Ministry of Health notes that, in 1988-89 the Ministry of Health spent $\$ 83,388,725$ on community mental-health programs (Ontario Ministry of Health, 1989). For 1989-90, estimated expenditures rose to $\$ 108,487,500$. Unfortunately, the Estimates Briefing Report supplies no data on the number of clients served nor the number of places provided in various ministry-supported activities.

It is always estimated that the number of mentally ill people is larger than the number of developmentally handicapped people, although the actual figures may vary. Therefore, it is clear that in 1988-89 more funds for community projects were committed and, most likely, more services provided per capita to developmentally handicapped people than to mentally ill people.

Moreover, by 1987 the Government of Ontario was spending almost \$1 billion a year on all aspects of mental-health policy (Ontario Ministry of Health, 1989). ${ }^{2}$ Yet mental-health expenditure was lopsided: large institutions soaked up $35 \%$ of funds, OHIP expenditures for psychiatric services absorbed $23 \%$, psychiatric units in general hospitals took up about $22 \%$, while community mental-health services received only around five percent of funds and a variety of other programs absorbed the rest. Despite the fact that almost every government report since the 1930s had advocated increased expenditure on community mental health, the government seemed unable or unwilling to refocus policy on community care. It is true that in the summer of 1989 the Graham Report (Provincial Community Mental Health Committee, 1988) advocated a major reorientation of government policy and funds toward community mental-health programs, but at the time of writing, legislation is still in the drafting stage while the amount of funding devoted to community mental health still has a long way to go before it catches up with psychiatric hospitals and psychiatric units. Thus, changes are afoot in mental-health policy, but radical reforms similar to those that occurred in policy for persons with developmental handicaps have yet to be implemented.

What explains the difference?

(1) Language. Language is a weapon in the political process (Boudreau, 1987; Rochefort, 1988; Schon, 1971). Slogans, phrases, catchwords, and labels are essential elements in fighting political battles. For a long time parents, pressure groups, and sympathizers fought to change the way people talked about developmentally handicapped people. As a result, terms like "idiot," "imbecile," "feeble-minded," and "moron," all of which had been adopted at the end of the 19th and early 20 th centuries as scientific descriptions of different levels of intelligence, took on negative connotations and were discarded. The term "mental retardation," and the phrase "developmentally handicapped people" were adopted in an attempt to paint a more positive picture of people who we now refer to as developmentally handicapped.

Although not all developmentally handicapped people are children, and many developmentally handicapped people do not conform to contemporary notions of beauty or good looks, the Ontario Association for the Mentally Retarded 
(OAMR) (now the Association for Community Living) was always careful to depict normal-looking children in its literature and advertising. This was part of a campaign to get the public, and thereby the government, to accept the idea that developmentally handicapped people were children, harmless, and looked like most people. To this day, when people think of developmentally handicapped people, they often think first of children rather than adults.

Another important development in the realm of language was the adoption of the term "normalization"' (Wolfensberger, 1972). The term referred to providing developmentally handicapped people with an environment that was as close to normal as possible. It was rarely used in the area of mental health since it implied that the person to be dealt with would always need some help and protection, a suggestion which many providers and consumers rejected as irrelevant to many forms of mental illness. Normalization was a wonderful weapon to use in the political struggle for better care for developmentally handicapped peoplefor who could be against it? It had the peculiar quality of appealing to society's sense of fairness and justice as well as having about it a ring of science, as if lined up behind the concept were the entire community of medical doctors and professionals endorsing OAMR policies.

The same holds true for the term "deinstitutionalization." Here too, the OAMR was able to win support because after the 1960 s the big institutions fell into disrepute. Antipsychiatrists such as R.D. Laing and Thomas Szasz and the immensely influential sociologist Erving Goffman all published their major attacks on institutions almost simultaneously in 1960-61 (Goffman, 1961; Laing, 1960; Szasz, 1960). Their critiques came at a time when students, blacks (especially in the United States), and intellectuals were launching an unprecedented attack on all large institutions including government, universities, corporations, and, of course, mental-retardation facilities and psychiatric hospitals. These attacks, combined with government cost-saving measures, contributed to the large-scale deinstitutionalization of developmentally handicapped and mentally ill people beginning in the mid-1960s.

However, differential success in the deinstitutionalization of developmentally handicapped and mentally ill people brought the term into disrepute. Whereas, in Ontario, group homes and other living arrangements for developmentally handicapped people were made available (although, consumer and interest groups complained, never in sufficient number), in the early stages of deinstitutionalization, mentally ill people were virtually dumped into the community. The term normalization was associated with the relative success of policy for the developmentally handicapped, while deinstitutionalization was associated with the failures of community mental-health policy and, particularly, with the thousands of homeless mentally ill who roamed the major urban areas of Ontario. ${ }^{3}$

Finally, two additional terms, "community care" and "community living," became popular during this time. Yet few people asked tough questions such as: "What is the community and where is it?" It was assumed that since institutionalization was the worst thing in the world, deinstitutionalization into the community was a positive and necessary alternative to the large institution. However, while developmentally handicapped people were sent to group homes or other 
"community living" structures, many psychiatrists wrongly assumed modern drug therapy would be sufficient support to help mentally ill people fend for themselves in the community.

Currently, mental-health groups have not succeeded in finding and popularizing a term as powerful as normalization. The term deinstitutionalization no longer had the same positive connotation in the 1980 s as it had in the 1960 s and 1970 s. Even references to the community or to community living no longer evoke the same uncritical response as a few years ago. And opposition to group homes by ratepayers and some local governments has cast a shadow over community services for mentally ill people.

To be successful in the political arena, terms, slogans, or phrases must convey ideas that express policy goals and also elicit a positive response from the public, politicians, and bureaucrats. The ideas evoked by mental-retardation groups met with a ready and positive response in the 1960 s and 1970s. Unfortunately, the language used by mental-health groups in the late $1970 \mathrm{~s}$ and $1980 \mathrm{~s}$ has not elicited the same reaction.

(2) Money. Although politics is not exclusively about money, nine-tenths of it is. In this area, mental-retardation pressure groups were lucky because they began their campaigns for special classes for developmentally handicapped children in 1948 and for deinstitutionalization in 1960, at a time when the provincial economy was booming and the government was awash in funds. In 1950 total government expenditures equalled $\$ 235,400,000$. By 1960 , provincial expenditures had expanded three-fold to $\$ 749,000,000$, and by 1970 , it had increased six-fold to $\$ 4,251,000,000$. The deficit was low and revenues were high. Thus, the financial climate of the 1950 s and 1960 s was propitious for new and costly policy initiatives.

There was one additional factor: In 1966 the federal government established the Canada Assistance Plan (CAP) which provided for a $50 \%$ reimbursement of provincial social-assistance expenditures for persons " in need." People in provincial institutions including psychiatric hospitals and mental-retardation institutions run by the Ministry of Health were not eligible for CAP funds.

In order to profit from CAP the province transferred jurisdiction over mental-retardation institutions from the Ministry of Health to ComSoc. Developmentally handicapped people who had been classified as patients under Health, and were ineligible for CAP funding, thereby became residents, and eligible for CAP funds. At one stroke, the province had cut its expenditures on developmentally handicapped people in half. And because politicians, bureaucrats, and pressure groups enthusiastically supported deinstitutionalization, normalization and community care, it was not difficult to argue that additional funds from CAP should go to community care. It is an open question as to whether mental-retardation groups would have been quite so successful in achieving their educational and community integration goals if the public expenditure situation had been less positive. But, given the fact that in the current era of government austerity, less money still is spent on community services for mentally ill people than for developmentally handicapped people, it is likely that the relative positions of the two policies would have been the same. 
In contrast with policy for the developmentally handicapped, from the very inception of medicare the federal government refused to allow the provinces to use federal funds for psychiatric hospitals. The feds hoped thereby to force the provinces to reduce the size of provincial institutions and move toward community care, which was assumed to be cheaper. But rather than go the American route of establishing free-standing community mental-health centres, by the 1960 s Ontario defined community care as referring to psychiatric units in general hospitals. There were a number of reasons for this: Local communities were reluctant to share the cost of financing, psychiatrists were anxious to find a place in general hospitals where they could share the prestige and financial rewards of their colleagues in physical medicine, and the psychiatric community told political decision-makers that community care in psychiatric units was the most appropriate form of treatment for mental illness (Canadian Mental Health Association [CMHA], 1963; Simmons, 1990).

Moreover, with the rising deficits of the late 1970s, the Ontario government desperately sought to reduce public expenditure. Since mental-health policy was never popular, and since the ministry already had to meet enormous fixed costs in the form of 10 psychiatric hospitals, the indirect costs of psychiatric units, psychiatrists' fees, and other mental-health expenses, the government did not (and still does not) look kindly on new and expensive initiatives in community mental-health care.

(3) Pressure groups. Pressure groups play a key role in the policy process. There are few rules in the politics of disability, but one rule is that services will be poorly funded and minimally provided in a policy field where there are no pressure groups.

The OAMR played a crucial role in the determination of policy for the developmentally handicapped from the 1950 s to the 1980s. Established in 1948 (it was then called the Ontario Association for Retarded Children [OARC]), it quickly grew into an organization with more than 10,000 members. Half of the membership consisted of parents of developmentally handicapped people, but half were interested citizens. The members came from all walks of life, some had contacts in government, and a few were on a first-name basis with former Premier William Davis. As well, during the crucial decade of the 1970 s, the wife of the provincial secretary for social development was a member of the OAMR. Other cabinet members also had links with the OAMR.

The OAMR used the traditional methods open to pressure groups: It provided politicians, bureaucrats, and the public with information about mental retardation and it skillfully used the press to publicize its cause. Above all, the OAMR established lines of communication with relevant bureaucrats in the key ministries, especially in the Ministries of Health and Community and Social Services. The appointment in 1965 of Dr. Donald Zarfas, director of the Children's Psychiatric Research Institute in London, Ontario and an ardent friend of the OAMR as director of the mental retardation services branch in the department of health was a sign of the OAMR's influence. When Dr. Zarfas left government, the OAMR lost a key access point to government.

By contrast the Canadian Mental Health Association-Ontario Division (CMHA-Ontario) has not been as effective as the OAMR. There are a number of 
reasons for this. Unlike the OAMR, there are fewer parents or relatives of mentally ill people in the CMHA-Ontario than in the OAMR. However committed they may be, CMHA-Ontario members have not fought their political battles with the same passion and emotional commitment as was the case with the OAMR. In a 1988 interview, former Minister of Health Larry Grossman maintained that in the 1970 s there was no constituency for mental health either within or outside the government (L. Grossman, personal communication, November 2 , 1987). Members of mental-health consumer groups have accused the CMHAOntario of being too close to government (D. Weitz, personal communication, March 14, 1988).

Another problem has been the proliferation of mental-health pressure groups in the 1980 s. Unlike the mental-retardation field in the 1970 s, where the OAMR could claim with some justice to represent the vast majority of those involved in or concerned with policy for the developmentally handicapped, in the late 1970 s in the mental-health field a number of groups such as On Our Own, Friends of Schizophrenies, and Phoenix Rising were established outside of and often in opposition to CMHA-Ontario. The conflicting demands these groups make on government necessarily undermines their effectiveness. For example, Friends of Schizophrenics takes a pro-commitment line and tends to support traditional treatment measures more than most self-help groups. Unlike developmental handicap where there is a wide degree of consensus on etiology and diagnosis, the etiology and indeed the very nature of mental illness are surrounded by controversy (Dain, 1989). Different interpretations of mental illness lead to different policy recommendations with the result that government finds that whatever policies it implements alienate one or another of the mental-health pressure groups.

Finally, unions are an important element in the pressure-group field. Provincial institutions are run directly by the government rather than by hospital boards as is the case with general hospitals. Institutional employees work for the government-and they are unionized. Any government contemplating major changes in policy toward the large institutions must be ready to negotiate with, or enter into conflict with, trade unions. Although it is not inevitable that governments and their unionized employees will conflict when major policy reforms are in the offing, few governments enter into such reforms lightly. Historically, there have been two major institutions for the developmentally handicapped in Ontario-the Huronia Regional Centre and the Rideau Regional Centre-while there are currently 10 psychiatric hospitals. Taking on the employees at the psychiatric hospitals would prove a much bigger task than the government confronted when scaling down facilities for the developmentally handicapped in the late 1970 s.

(4) The press. One should not underestimate the role that the press plays in the political process. The advisers to cabinet ministers assiduously clip the major newspapers every day in order to prepare them for possible questions from the opposition parties in the legislature or to answer questions from the press or the public.

Over the years the plight of developmentally handicapped people has consistently received a better press than the plight of mentally ill people. For exam- 
ple, an article by Pierre Berton in the December 31, 1959 Toronto Star exposing the terrible overcrowding and deteriorating condition at the Huronia Regional Centre led to a meeting between then Premier Leslie Frost and representatives of the OARC and to the beginning of two decades of reform in policy for the developmentally handicapped (Simmons, 1983). In 1971, when a resident who had wandered from Smith's Falls (Rideau Regional Centre) froze to death, articles in the Ottawa and Toronto press led to the appointment of Toronto lawyer Walter Williston to investigate policy for the developmentally handicapped (Williston, 1971). Williston's report crystallized sentiment around implementing major policy changes. By contrast, although the Toronto press is generally sympathetic to the plight of residents in mental hospitals and particularly to the housing problems facing ex-patients, occasional articles about crimes committed by ex-mental patients or community fears of group homes convey a mixed message to the public. ${ }^{4}$

(5) Opposition political parties. Opposition parties are constantly on the alert for issues with which they can embarrass the government. Obviously the government does not like criticism and it responds quickly to it in two ways: First, it may deny opposition accusations; second, it may admit that the criticism has some basis in fact, but it will always minimize the problem, while promising to look into the issue. Frequently, behind the scenes there is frantic activity to correct what in fact may be a defect in policy.

During the 1960 s and 1970 s the New Democratic Party (NDP) clearly led the field in criticising the government on policy for the developmentally handicapped, although in the late 1970 s, some Liberal members of the legislature became effective critics of government policy. Opposition parties are also conduits for pressure groups. Pressure groups play a very delicate game, trying on the one hand not to alienate completely government for fear of losing all influence over policy, but at the same time carefully trying to maintain links with opposition parties which can be used to influence a stubborn or insensitive government. During the 1970 s and 1980 s, the OAMR walked this tightrope with enormous skill, It was not identified with either the opposition New Democratic or Liberal parties, yet it maintained contacts with both while also enjoying good relations with the Progressive Conservative government.

With regard to mental-health policy the opposition parties have played their traditional role, but with a difference. From 1976 to 1982 Dr. Stuart Smith, a psychiatrist with very strong views about mental-health policy, was the leader of the Liberal Party. During 1977-1978 Dr. Smith actively opposed amendments to the Mental Health Act narrowing the grounds for involuntary admission of patients to psychiatric hospitals (Legislative Assembly of Ontario, 1978). In addition, from 1971 to 1980 Dr. Jan Dukszta, a Toronto psychiatrist, was a member of the New Democratic Party and an influential force in determing NDP mentalhealth policy. During that time Dr. Dukszta generally supported deinstitutionalization and the establishment of community mental-health services. However, during the 1970s, the two opposition parties took different positions on mental-health policy, thereby allowing the government a freedom of action it might not have had if it had been faced with a united opposition. 
Opposition political parties in parliamentary systems have fewer levers of influence at their command than their counterparts in the American congressional system. In the American political system, there is no official opposition; political parties are divided, undisciplined, and weak. Moreover, because legislative committees play a determining role in formulating policy, the support of a few key committee chairmen can facilitate the task of pressure groups intent on blocking or undermining policies (Marmor \& Gill, 1989). Because it offers so many access points to pressure groups, the American congressional system is structurally biased against change. On the other hand, because the Canadian parliamentary system places so much power in the hands of the majority party and the executive, it prevents pressure groups from blocking legislation while at the same time facilitating policy change.

(6) The bureaucracy. This is where the power lies in the Ontario system and in most parliamentary systems. Individual ministers have only limited time and energy to devote to specific issues such as developmental handicap or mental health. Unless pressure is brought to bear on a minister directing her attention toward mental health or developmental handicap, most of her time will be spent on the big ticket items such as hospitals or physicians' incomes.

In these circumstances the role of the deputy minister and of the assistant deputy minister is extremely important. Most bureaucrats insist they do not make policy - and indeed in their own minds they do not. But they do have a major influence on policy. After all, they help to set the minister's agenda, they advise her about which policies should be funded and which should be cut, and they frequently know how to obtain scarce funds for pet projects.

During the 1960s and 1970 s the OAMR had a major influence on the top bureaucrats. The OAMR constantly bombarded bureaucrats with information and with appeals, both from the central office in Toronto as well as from the local associations scattered around the province. The appointment by Minister of Health Matthew Dymond of Dr. Donald Zarfas to head the mental retardation services branch in 1965 has already been mentioned (Simmons, 1983). From this vantage point, and with the collaboration of other bureaucrats sympathetic to his views, Dr. Zarfas was able to implement major reforms in the field. Over the years that followed the OAMR found valuable allies within ComSoc, and in Robert Welch, provincial secretary for social development.

The contrast with mental-health policy could not be more stark. Whereas in the 1970 s the OAMR was the tail that wagged the bureaucratic dog, in mental health the bureaucracy has always been the dominant force. Over the years the Ministry of Health has established, disbanded, and then created a mental-health branch or mental-health division charged with administering most aspects of mental-health policy. Until the 1980 s, a psychiatrist was usually in charge of the branch or division and mental-health priorities were set as a result of interaction between the Ministry of Health, the psychiatric community, and the psychiatrists who manned provincial institutions or psychiatric units in general hospitals. Mental patients, their friends and relatives played a relatively minor role in this process.

There were two major reasons for the early demise of the medical model in policy for the developmentally handicapped and its continuing persistence in 
mental-health policy. The first was that by the 1960 s it was broadly accepted that developmental handicap was a genetically determined condition for which the medical model had little relevance. By contrast, most psychiatrists argue that whatever the genetic component of mental illness, their unique training is vital for alleviating the pain and problems of mental illness. Second, although some conditions associated with developmental handicap may be amenable to treatment with drugs, they play a much smaller role than in the treatment of mental illness. Here too, psychiatrists successfully argued that their medical education and their specialist knowledge of drugs necessarily gives them a key role in dealing with mentally ill people. This attitude, combined with their foothold in the psychiatric units, has made the psychiatric community resistant to establishing communitycare services independent of the institutions and the psychiatric units.

(7) The minister of health. However well-intentioned they may be, bureaucrats do not make policy against the minister's wishes, or secretly without the minister's knowledge. They have enormous influence, but they lack the minister's authority. Thus, a lot will hinge on the personality and interests of the minister of health of the day. If, for some reason, the minister of health is interested in disability policy, then the bureaucracy can inflect policy in a particular direction. But even then a minister must have good political reasons for allocating scarce political resources-that is, time, energy, money, and publicity-to a particular policy.

The relationship between political priorities and outside pressure can be illustrated by an apocryphal story concerning American President Franklin Delano Roosevelt. One day he met with representatives of various pressure groups to discuss a particular issue. At the end of the meeting, President Roosevelt told his audience that he was completely converted to their views and to their policy recommendations. "Now," he said, "all you have to do is go out and make me do what I want to do."

Whether or not a particular issue becomes a political priority depends not only on whether one has made a convincing case, but particularly on the political clout one can muster. Once that clout is mustered then the politicians and bureaucrats begin to stir.

For example, in the early 1980, the Progressive Conservative government was under fire from the media, the opposition, and pressure groups because of the lack of affordable housing for ex-mental patients. When he became minister of health in 1982, Larry Grossman decided to give top priority to mental-health policy because, he said, "there was a crying need" (Grossman, 1988). But what caused him to perceive this need? As far as can be seen, Grossman's interest in mental-health policy was not sparked by some personal or family concern. Rather, he entered office at a time of widespread public debate about mentalhealth policy and about housing for mentally ill people. Grossman seems to have felt that as a new minister of health he could enhance his reputation in a field that was rife with controversy, in the public eye, and "do-able." At this point, the bureaucracy swung into action and helped Grossman to lay the foundation for major improvements in affordable housing for ex-mental patients and the establishment of a patient advocate program in Ontario's psychiatric hospitals. On its own, the bureaucracy could not have implemented these policies, but when the opportunity came, it was ready with suggestions for reform. 
The minister of health can organize the bureaucracy so as to facilitate access by pressure groups and ease the process of policymaking, or he/she can erect barriers and obstacles to groups and to policy formulation and implementation. The creation of a mental-health branch or division with a single person at its head will, ceteris paribus, make it easier for pressure groups, the media, and concerned individuals to express their views and to get the attention of the bureaucracy than if responsibility for mental-health policy is scattered across the ministry. For example, a great leap forward in the provision of affordable housing for ex-mental patients occurred in 1981 when Larry Grossman appointed an assistant deputy minister for public and mental health. Mental health became even more visible in December, 1984 when Minister of Health Keith Norton created the post of assistant deputy minister for mental health.

More recently, as part of that Spenglerian cycle of reorganizations that seems endemic in bureaucracies, deputy minister of health Dr. Martin Barkin ordered a major reorganization of the ministry along matrix management lines with the result that responsibility for mental-health policy was divided among different civil servants. Diffusing responsibility for mental-health policy may lead to confusion and inaction, but it is too early to determine whether the matrix system will in fact succeed where other similar systems have failed.

(8) The professions. Experts, usually medical doctors or psychiatrists, have had an immense influence in the disability policy field. They staffed and directed the provincial institutions from their inception in the middle of the 19th century in Ontario. Typically they also staffed the upper reaches of the relevant bureaucracies in the Ministries of Community and Social Services and Health. It was not until 1945 that parents, friends, or relatives of developmentally handicapped persons established pressure groups that were not dominated by medical doctors or other professionals whose interest in the disabled was either paternalistic or inspired by fear.

However, professionals in the developmental-handicap and mental-health fields have behaved differently toward their client groups. By the mid-1970s physicians' influence over policy for the developmentally handicapped had begun to fade in the face of challenges from social workers, professional administrators, and experts in the helping professions. Few medical doctors resisted the trend toward deinstitutionalization of developmentally handicapped people and many supported it. Although there is still a debate about the size of that minority of developmentally handicapped people who, it is claimed, will always need institutional care, there is a general consensus that the preferred alternative is community living and integration.

In the mental-health field, however, the course of events has been different. Psychiatrists have not yet forsaken their claims to expertise and conceded authority to non-medical experts. They continue to claim professional authority on two grounds: first, that only qualified medical doctors are equipped to deal with diseases like schizophrenia which, it is claimed, have a genetic basis and are bio-chemical in origin; and second, that expert training and experience in the diagnosis and classification of mental illness is the necessary basis for treatment. By staking a claim to expertise in treating mental illness either as a disease (in the case of schizophrenia), or as a purely psychological disorder, psychiatrists have 
been able to hold the line against attacks from antipsychiatrists, social workers, psychologists, and consumer groups.

Although most psychiatrists would probably agree that large institutions should be reduced in size, most would probably support the notion that mental illness can best be treated in psychiatric units located in general hospitals. Because of the drug revolution many psychiatrists insist that their professional expertise is necessary for the proper treatment of mentally ill people. Moreover, recent research into the genetic and bio-chemical causes of illnesses such as schizophrenia has borne sufficient fruit to convince government to devote more funds to further research and to convince the public that research into mental illness is not that much different from research in the "hard" sciences.

(9) The law. The law provides a framework for policy, but the law can be altered and is itself a subject of the political game. Most of the time attitudinal and other changes (socio-economic, institutional, scientific) precede and cause changes in law. For example, the recent weakening of the legal authority of psychiatrists and increases in patients' rights occurred as a result of growing public suspicion of and hostility to psychiatrists evoked by revelations of abuses of psychiatric authority, media criticism of contradictory psychiatric testimony during sensational murder trials, and criticism of the relevance of the medical model for the field of disability (Simmons, 1990).

Whereas advocates for developmentally handicapped people focused their energies primarily on policy, groups working for mentally ill people have brought about major changes in mental-health law (Savage \& McKague, 1987). The primary focus had been on questions of involuntary institutionalization and compulsory treatment. In 1967 a new Mental Health Act was passed which established hopsital boards of review to review committal decisions. And in 1978, thanks to activist mental-health lawyers and a reformist minister of health (Dennis Timbrell), the rights of mentally ill people to refuse treatment and to resist committal were vastly extended.

But, while there is little question that developmentally handicapped people often need guidance or help in making decisions, there is currently a furious debate in the mental-health field over the question of responsibility. At issue are basic questions of the nature and meaning of mental illness. Groups working for schizophrenics tend to support broadening psychiatrists' authority to compulsorily admit and treat people with certain kinds of schizophrenia. But other mentalhealth pressure groups oppose this position. Moreover, public attitudes toward mentally ill people, as illustrated by frequent opposition to group homes, are often characterized by fear and suspicion. Thus, disagreement over basic questions of the nature of mental illness will probably lead to a political and legal stalemate which, in turn, will terminate the process of mental-health law reform that lasted from the late 1960 s to the late 1980 s.

\section{CONCLUSION}

This schematic analysis of the major influences on developmental-handicap and mental-health policy obviously suffers from one defect: the absence of ranking. Unfortunately, there is no way to establish such a ranking. Even the most likely candidate for the major independent variable influencing policy, that is, 
changing conceptions and models of mental illness, turns out on closer scrutiny to be highly contingent. After all, there is today an enormous literature on the history of madness which argues that illness models are themselves highly subject to the vagaries of historical, political, and social forces (Ray, 1981; Scull, 1979).

Except for limited periods of time, looking for the prime mover of policy is a fruitless task. The political process is dynamic and unsystematic. Influence waxes and wanes, links and networks are established, broken, and re-formed. New terms appear, are challenged, redefined, and disappear. No wonder that those who actually participate in the political process-as opposed to those who analyze it from the outside and after the fact-often feel as if they are in the middle of a kaleidoscope, pushed this way and that by random influences, and hardly able to determine which way they are headed or what is necessary to reach their destination.

If it were possible to identify the prime mover of policy, then the policy puzzle could be solved and recipes for effective political action concocted. Given the complexity of the problem, however, one can only attempt to catch, and to accurately identify for a fleeting moment, those influences which impinge on the policy process.

\section{NOTES}

1. On 24 March, 1974 Project '77, a submission to cabinet by the department of health, noted that there was a "need for revision and rationalization of the mental health program in accordance with changes in public attitudes, and current methods of treating mental disorders: i.e., treating the patient as close to his community as possible and avoid [sic] the harmful effects of institutional placements" (p. 1). The proposal suggested transferring 2,000 "long-term psychiatric patients from mental hospitals, to suitable placements in the community," and transferring 2,000 "retardates ... to space in psychiatric hospitals" (p. 1). The proposal regarding developmentally handicapped people was never implemented because, after responsibility for developmentally handicapped people was transferred from the Ministry of Health to the Ministry of Community and Social Services (ComSoc), ComSoc moved directly to transferring people to various forms of community accommodation.

2. The Ministry of Health lumped the following under mental-health expenditures: OHIP payments, community mental health, alcohol and drug programs, psychiatric hospitals, general hospitals, homes for special care, local health agencies, grants to associations, research grants, and health resource development.

3. The provincial community mental health committee estimated in 1988 that there were 12,000 homeless former psychiatric patients (Provincial Community Mental Health Committee, 1988, p. 20).

4. In the fall of 1980 there was a series of articles on dangerous mental patients and in 1981 on public opposition to group homes for ex-mental patients. See The Toronto Star: October 22, 1980, July 5, 1981, and July 8, 1982 and the Globe and Mail: July 30, 1980, and July 28, 1981. A press study of eight Canadian newspapers, including the Globe and Mail and The Toronto Star found "that the treatment of the mentally ill and mental health concepts is essentially of a critical nature with a preponderance of statements which indicate problems within the mental health care system. However, there are more statements which convey information about community mental health that are consistent with the ideals of a movement toward deinstitutionalization than statements which advocate a return to custodial mental health care" (Day, 1984, p. 73). 


\section{RESUME}

On admet généralement que la politique pour les personnes handicapées intellectuelles a été mieux réussie que la politique pour la santé mentale. La raison pour cela est expliquée à partir de neuf variables-clés ayant un impact majeur sur le développement d'une politique: la langue, l'argent, les groupes de pression, la presse, les partis politiques d'opposition, la bureaucratie, le ministre de la santé, les professions, et la loi. Ces variables ne sont pas ordonnées entre elles parce que, avance-t-on, il est impossible de bien saisir les processus liés politiques en ètablissant une hiérarchie de ces influences.

\section{REFERENCES}

Boudreau, F. (1987). The making of mental health policy: The 1980 s and the challenge of sanity in Quebec and Ontario. Canadian Journal of Community Mental Health, $6(1)$, $27-48$.

Canadian Mental Health Association. (1963). More for the mind. Toronto: Canadian Mental Health Association.

Dain, N. (1989). Crities and dissenters: Reflections on "anti-psychiatry" in the United States. Journal of the History of the Behavioral Sciences, 25, 3-25.

Day, D.M. (1984). Portrayal of illness in the media: A content analysis of Canadian newspapers. Unpublished master's thesis, University of Windsor, Windsor, ON.

Department of Health. (1974). Submission to Cabinet. Toronto: Archives of Ontario.

Goffman, E. (1981). Asylums. New York: Anchor Books.

Laing, R.D. (1960). The divided self. London: Tavistock Publications.

Legislative Assembly of Ontario. (1978). Debates. Standing social development committee hearings on Bill 19, the Mental Health Amendment Act.

Marmor, T., \& Gill, K.C. (1989). The political and economic context of mental health care in the United States. Journal of Health Politics, Policy and Law, 14(3), 459-475.

Ontario Ministry of Community and Social Services. (1989). Program and resource summary: 1989.90 estimates. Toronto: Author.

Ontario Ministry of Health. (1988). Regional allocation of estimated expenditures on mental health services by ministry of health, 1986-87. Toronto: Author.

Ontario Ministry of Health. (1989). Estimates, briefing report: 1989-90. Toronto: Author.

Provincial Community Mental Health Committee. (1988), Building community support for people: A plan for mental health in Ontario. Toronto: Ministry of Health.

Przeworski, A., \& Teune, H. (1970). The logic of comparative enquiry. New York: WileyInterscience.

Ray, L.J. (1981). Models of madness in Victorian asylum practice. European Journal of Sociology, 22(2), 229-264.

Rochefort, D. (1988). Policymaking cycles in mental health: Critical examination of a conceptual model. Journal of Health Politics, Policy and Law, 13(1), 139-141.

Savage, H., \& MeKague, K. (1987). Mental health law in Canada. Toronto: Butterworth.

Schon, D. (1971). Beyond the stable state. New York: W.W. Norton.

Scull, A. (1979). Museums of madness. New York: Penguin Books.

Simmons, H.G. (1983). From asylum to welfare. Toronto: National Institute on Mental Retardation.

Simmons, H.G. (1990). Unbalanced-mental health policy in Ontario, 1930-1989. Toronto: Wall \& Thompson.

Szasz, T. (1960). The myth of mental illness. The American Psychologist, 15, 113-118.

Williston, W. (1971). Present arrangements for the care and supervision of mentally re- 
tarded persons in Ontario. Ontario: Department of Health.

Wolfensberger, W. (1972). The principle of normalization in human services. Toronto: National Institute on Mental Retardation. 